\title{
Sunlight Exposed Body Surface Area is Associated With Serum 25-hydroxyvitamin D (25(OH)D) Level in Pregnant Minangkabau Women, Indonesia
}

Cimi Ilmiawati ( $\square$ ilmiawati@med.unand.ac.id)

Andalas University Faculty of Medicine https://orcid.org/0000-0001-5743-3331

Athica Oviana

Postgraduate Program of Midwifery, Faculty of Medicine Andalas University

Andi Friadi

Department of Obstetrics and Gynecology Faculty of Medicine Andalas University

Research article

Keywords: body surface area, pregnant, sunlight exposure, vitamin D

Posted Date: October 18th, 2019

DOI: https://doi.org/10.21203/rs.2.16199/v1

License: (c) (i) This work is licensed under a Creative Commons Attribution 4.0 International License.

Read Full License 


\section{Abstract}

Background: Vitamin D deficiency is highly prevalent in women, while living in a tropical country with year-round abundance of sunlight as the main source of vitamin $D$ does not seem to guarantee adequate serum 25(OH)D. While living in the tropics, Minangkabau women are known to dress specifically according to their culture. This study was aimed to elucidate the association of sunlight exposed body surface area with serum 25(OH)D in pregnant Minangkabau women of Indonesia. Methods: A crosssectional study was carried out on 88 Minangkabau women in late pregnancy. Data were collected by using questionnaire and 24-hour food recall, skin pigmentation was determined by Fitzpatrick scale, body surface area exposed to sunlight was assessed and serum 25(OH)D was quantified by ELISA method. Results: Nearly half of the subjects $(n=40 ; 45.5 \%)$ were deficient in vitamin $D(<20$ $\mathrm{ng} / \mathrm{ml}$ ) with serum $25(\mathrm{OH}) \mathrm{D}$ level $23.0 \pm 10.0 \mathrm{ng} / \mathrm{ml}($ mean $\pm \mathrm{SD})$ and estimated daily intake of vitamin $\mathrm{D}$ $5.6 \pm 3.9 \mu \mathrm{g} / 1000 \mathrm{kcal} /$ day (mean $\pm \mathrm{SD}$ ). Median percentage of body area exposed to sunlight was $15.8 \%$. There were no differences in serum $25(\mathrm{OH}) \mathrm{D}$ levels according to sunlight exposure time, skin pigmentation type, and sunscreen use. Percentage of body area exposed to sunlight was positively correlated with serum 25(OH)D level (Spearman's $\rho=0.403 ; p<0.001)$. Conclusions: Vitamin D deficiency is prevalent in pregnant Minangkabau women and they need to consider increasing their body area exposure to sunlight. Keywords: body surface area, pregnant, sunlight exposure, vitamin D

\section{Background}

More than one billion people were deficient in vitamin D (Holick, 2011) making in a public health concern (Mithal, 2009). In South Asia, the prevalence of vitamin D deficiency (VDD) was estimated to be $70 \%$ or more while in South-East Asia it varies between 6-70\% (Nimitphong \& Holick, 2013). In China, it is reported that $63.7 \%$ pregnant women were vitamin D deficient $(25(\mathrm{OH}) \mathrm{D}<50 \mathrm{nmol} / \mathrm{L}$ ) (Yuan et al, 2017), while in Turkey the number was $94.8 \%$ (Pehlivan et al, 2002). In Vietnam, $60 \%$ of women in late pregnancy had low serum 25(OH)D level ( $<75 \mathrm{nmol} / \mathrm{L}$ ) (Hanieh et al, 2014). A study in Kenya, a tropical country, showed that $51 \%$ of women had insufficient $(<75 \mathrm{nmol} / \mathrm{L})$ and $21 \%$ had deficient serum $25(\mathrm{OH}) \mathrm{D}$ level $(<50$ $\mathrm{nmol} / \mathrm{L}$ ) (Toko et al, 2016). VDD in pregnant women needs particular attention because of the potential unwanted birth outcome.

VDD during pregnancy may adversely affect the fetus, the newborn child, and even the early childhood. Monitoring serum level of $25(\mathrm{OH}) \mathrm{D}$ during antenatal period is warranted as a preventive measure to decrease morbidity during pregnancy and lactation period, and to mitigate adverse effect on the fetus, newborn, and child (Urrutia-Pereira \& Sole, 2015). Studies in Poland and the US found that VDD in pregnant women with serum $25(\mathrm{OH}) \mathrm{D}<75 \mathrm{nmol} / \mathrm{L}$ was associated with increased risk of preeclampsia (Domaracki et al, 2016; Amegah et al, 2017). Lower serum 25(OH)D has been shown to associate with increased risk of macrosomy and vitamin D supplementation is advised during pregnancy (Wen et al, 2018). A study in Kenya showed that vitamin D insufficiency is associated with neonatal stunting (Toko 
et al, 2016). Identifying factors related to serum $25(\mathrm{OH}) \mathrm{D}$ in a specific population is important to devise appropriate measures.

Geographical factor; like season (Van der Mei et al, 2008) and latitude (Kimlin et al, 2007), affects the intensity of ultraviolet B (UVB) radiation as the main source of vitamin D3 synthesis in the exposed skin (eds. Ross et al, 2011). Other factors such as skin pigmentation type (Nair \& Maseeh, 2012), amount of sunlight exposed body surface area (Lee \& Choi, 2009), sunscreen application and dressing (Misra et al, 2008) may also influence serum 25(OH)D level. Daily dressing habit may affect serum 25(OH)D level because the type of fabric used may prevent UVB radiation absorption by the skin. Moreover, the size of body surface area exposed to sunlight determines the amount of vitamin D synthesis in the skin (Misra et al, 2008).

Minangkabau women living in West Sumatra, Indonesia, are known to adhere to culturally acceptable dressing code in their daily life. It is common to cover whole body area except the face, hands and feet. A recent study in young Minangkabau women found that $97 \%$ of subjects were vitamin D deficient and that sleep quality, dietary intake, and sunscreen use were predictors of serum 25(OH)D (Silvia, 2019a). The research underlines that residing in tropical country does not guarantee the adequacy of serum vitamin $D$ and other factors need to be considered. Considering the highly prevalent low 25(OH)D serum in Indonesian women, the mostly body-covering dressing characteristic of Minangkabau women, and the limited study on pregnant women, we undertook a research examining the association of sunlight exposed body surface area with serum 25(OH)D level in Minangkabau women during late pregnancy.

\section{Methods}

This study was approved by the ethics committee of Faculty of Medicine Andalas University (Approval No.005/KEP/FK/2019). Eighty-eight last trimester pregnant women were recruited from February to June 2019 from a public health center in Padang by purposive sampling.

Subjects were interviewed by using a standardized questionnaire and 24-hour food recall for the last two days was employed to assess vitamin $D$ intake. Questionnaire-guided interview was performed to obtain data on duration of sunlight exposure during the last two days (in minute) (Kato et al, 2011), on habitual dressing when going outdoor (percentage of body surface area exposed to sunlight) (Lee and Choi, 2009), on skin pigmentation (Fitzpatrick's scale) (D'Orazio et al, 2013), and on sunscreen application (regular, irregular, non-user) (Misra et al, 2008). Skin pigmentation type was also assessed by observation (Sachdeva, 2009). 
Serum 25(OH)D level was measured by ELISA method by using 25(OH)D ELISA Kit (Can-VD-510) produced by Diagnostic Biochem Canada (DBC®) (Silvia et al, 2019b; Aji et al, 2019).

Statistical analysis was performed using parametric tests (Pearson correlation and One-Way ANOVA) on normally distributed data. Data with non-normal distribution were logarithmically transformed $(\log 10)$ to approximate normal distribution. Non-parametric test (Spearman correlation) was performed on data with non-normal distribution. Data with normal distribution are described as mean $\pm S D$ while data with non-normal distribution are described as median and range.

\section{Results}

Our findings showed that serum 25(OH)D level in third trimester pregnant Minangkabau women was $23.0 \pm 10.0 \mathrm{ng} / \mathrm{ml}$ (mean \pm SD) and estimated daily intake of vitamin D $5.6 \pm 3.9 \mu \mathrm{g} / 1000 \mathrm{kcal} / \mathrm{day}$ (mean $\pm S D$ ). Nearly a third (29.5\%) of the women were exposed to sunlight $<30$ minutes/day and median body surface area (BSA) exposed to sunlight was $15.8 \%$. Most of the subjects were of type $V$ skin pigmentation $(86.4 \%)$ and were non-sunscreen user (79.5\%). Other characteristics of subjects are presented in Table 1.

Comparisons were performed to examine whether the level of serum $25(\mathrm{OH}) \mathrm{D}$ in our subjects was different according to the duration of sunlight exposure, skin pigmentation type, and sunscreen use. The results showed that there was no statistically significant difference in serum $25(\mathrm{OH}) \mathrm{D}$ level according to the duration of sunlight exposure $(<30,30-60,>60-120$, and $>120 \mathrm{~min} /$ day; One-Way ANOVA; $p=0.63$; Figure 1), to skin pigmentation type (type III, IV, and V; One-Way ANOVA; $p=0.51$, Figure 2), and to sunscreen use (regular, irregular, and non-user; One-Way ANOVA; $p=0.72$, Figure 3).

To examine the correlation between serum 25(OH)D level with sunlight exposed BSA, Spearman's correlation test was performed and the results showed that there was a statistically significant linear correlation between serum 25(OH)D level and percentage of BSA exposed to sunlight $\left(R^{2}\right.$ linear $=0.153$; Spearman's $\rho=0.403 ; p=<0.001$; Figure 4).

\section{Discussion}

Recent studies showed that VDD is common in Indonesian women (Aji et al, 2019; Putri et al, 2019; Silvia et al, 2019b). Our previous study in healthy young Minangkabau women found that $97.5 \%$ of subjects had VDD (Silvia et al, 2019b). In line with previous findings, in this study, we find that $81.8 \%$ of pregnant women have insufficient/deficient serum 25(OH)D level according to the scientific consensus (Grant \& 
Holick, 2005). Serum 25(OH)D level in our study $(23.0 \pm 10.0 \mathrm{ng} / \mathrm{ml}$ (mean $\pm S D))$ is similar to those of pregnant women in other areas in West Sumatra $(25.4 \mathrm{ng} / \mathrm{ml}$; Putri et al, 2019), but higher than those of young Minangkabau women (median $10.5 \mathrm{ng} / \mathrm{ml}$; Silvia et al, 2019b).

VDD in pregnancy is of particular importance because it may adversely impact the health of the newborn (Toko et al, 2016). Minangkabau women living in West Sumatra is known to dress according to their culture where only the face, hands, and occasionally feet are exposed to sunlight. As UVB radiation from sunlight plays a main role in the dermal synthesis of vitamin $D$ from 7-dehydrocholesterol, the dressing habit that hinder sunlight exposure may affect serum vitamin D level (Misra et al, 2008). Our result supports this notion where we found that percentage of BSA exposed to sunlight correlates with serum $25(\mathrm{OH}) \mathrm{D}$ level, where $15.3 \%$ of serum $25(\mathrm{OH}) \mathrm{D}$ variability is explained by percentage of skin exposed to sunlight. Our result also in accordance with the finding of a cross-sectional study in Ethiopia where sunlight exposed BSA is a predictor of serum 25(OH)D level (Wayako et al, 2015). However, our finding is different from a study in healthy young Minangkabau women where no statistically significant correlation is found between sunlight exposed BSA and serum 25(OH)D (Silvia, 2019a). It is possible that the contrast between subjects is not enough in that study where $98 \%$ of the subjects wore hijab with median sunlight exposed BSA was $7.8 \%$. In the current study, not all of our subject wear hijab when going outdoor, some subjects choose to wear sleeveless dress, creating a contrast in data sufficient to detect the correlation between the degree of sunlight exposed BSA and serum 25(OH)D level.

As most of the subjects in our study wears hijab (whole body-covering garment) only around $15 \%$ of their body surface area are exposed to sunlight. Characteristics of fabrics used for the garment, such as colors, thickness and weaving mode, may affect the garment's effectivity in blocking UVB absorption by the skin (Diehl \& Chiu, 2010). Dark fabric two times more effective in absorbing UVB radiation compared to white one. There is a significant difference in vitamin $D$ synthesis between whole body exposure compared to face-hands-feets only exposure to sunlight (Misra et al, 2008). Sunlight UVB stimulates vitamin D synthesis from 7-dehydrocholesterol, where it will be stored in adipose tissue or be hydroxylated in the liver into $25(\mathrm{OH}) \mathrm{D}$ and undergoes further hydroxylation in the kidney to form the active calcitriol (Vidailhet et al, 2012).

Sound advise for pregnant women is to monitor their serum 25(OH)D level and to exposed their skin to sunlight for 7-25 minutes from 10 am to $3 \mathrm{pm}$, at least twice a week, where face, arms and legs are exposed without sunscreen application should be adequate to induce vitamin D synthesis (Holick, 2002; 2007). Our study underlines the importance of skin exposure to sunlight in pregnant women living in a tropical country. 


\section{Conclusions}

Vitamin D deficiency is prevalent in late pregnancy and increasing skin exposure to sunlight should be considered in pregnant Minangkabau women to mitigate this public health concern.

\section{Declarations}

\section{Ethics approval and consent to participate}

The research protocol was approved by the Committee of Medical Ethics (Approval No.005/KEP/FK/2019) of Faculty of Medicine Andalas. Thorough explanation of study objectives and protocol were given one week before the health examinations and written informed consent was obtained from each participant.

\section{Consent for publication}

Not applicable.

\section{Availability of data and material}

The dataset generated and/or analyzed during the current study are available from the corresponding author on a reasonable request.

\section{Competing interests}

None of the authors had any personal or financial conflict of interests.

\section{Funding}

This study was supported by grants from the Ministry of Research, Technology and Higher Education of Indonesia (KEMENRISTEKDIKTI) and from Andalas University (Hibah Percepatan Guru Besar Tahun 2018) to $\mathrm{Cl}$.

\section{Authors' contributions}


AO carried out the data collection, data analysis and wrote the manuscript. AF provided suggestions for the study design \& data analysis. Cl was responsible for obtaining funding, designing the study, providing feedback on data analysis and on manuscript writing and the overall management. All the authors approved the final version submitted for publication.

\section{Acknowledgements}

The authors would like to appreciate all of study participants. Special thanks to Ms. Lola Alviche, Ms. Rati Purwati and Mr. Muhammad Diki Juliandi for their contribution and assistance during data collection.

\section{References}

Amegah AK, Klevor MK, Wagner CL. 2017. Maternal vitamin D insufficiency and risk of adverse pregnancy and birth outcomes: a systematic review and meta-analysis of longitudinal studies, PLOS ONE. doi: 10.1371/journal.pone.0173605.

Aji AS, Erwinda E, Yusrawati Y, Malik SG, Lipoeto NI. 2019. Vitamin D deficiency status and its related risk factors during early pregnancy: a cross-sectional study of pregnant Minangkabau women, Indonesia, BMC Pregnancy and Childbirth. doi.org/10.1186/s12884-019-2341-4

D'Orazio J, Jarrett S, Amaro-Ortiz A, Scott T. 2013. UV radiation and the skin. International Journal of Molecular Sciences; 14(6): 12222-12248. doi: 10.3390/ijms140612222

Diehl JW, Chiu MW. 2010. Effects of ambient sunlight and photoprotection on vitamin D status. Dermatologic Therapy; 23(1): 48-60. doi: 10.1111/j.1529-8019.2009.01290.x.

Domaracki P, Sadlecki P, Odrowaz-Sypniewska G, Dzikowska E, Walentowicz P, Siodmiak J et al. 2016. Serum 25(OH) vitamin D levels in Polish women during pregnancies complicated by hypertensive disorders and gestational diabetes. International Journal of Molecular Sciences. doi: 10.3390/ijms17101574.

Grant WB, Holick MF. 2005. Benefits and requirements of vitamin D for optimal health: a review. Alternative Medicine Review; 10(2): 94-111. 
Hanieh S, Ha TT, Simpson JA, Thuy TT, Khuong NC, Thoang DD et al. 2014. Maternal vitamin D status and infant outcomes in rural vietnam: a prospective cohort study. PLOS ONE. doi:10.1371/journal.pone.0099005.

Holick MF. 2002. Vitamin D: the underappreciated D-lightful hormone that is important for skeletal and cellular health. Current Opinion in Endocrinology \& Diabetes; 9(1): 87-98. doi: 10.1097/00060793200202000-00011.

Holick MF. 2007. Vitamin D deficiency. New England Journal of Medicine; 357(26): 266-281. doi: 10.1136/bmj.318.7193.1284a.

Holick MF, Binkley NC, Bischoff-Ferrari HA, Gordon CM, Hanley DA, Heaney RP et al. 2011. Evaluation, treatment, and prevention of vitamin D deficiency: an Endocrine Society clinical practice guideline. Journal of Clinical Endocrinology and Metabolism; 96(7): 1911-1930. doi: 10.1210/jc.2011-0385.

Kato $\mathrm{M}$, lida M, Goto $Y$, Kondo T, Yajima I. 2011. Sunlight exposure mediated DNA damage in young adults. Cancer Epidemiology Biomarkers and Prevention; 20(8): 1622-1628. doi: 10.1158/1055-9965.EPI11-0228.

Kimlin MG, Olds WJ, Moore MR. 2007. Location and vitamin D synthesis: Is the hypothesis validated by geophysical data. Journal of Photochemistry and Photobiology B: Biology, 86(3): 234-239. doi: 10.1016/j.jphotobiol.2006.10.004.

Lee JY, Choi JW. 2009. Estimation of regional body surface area covered by clothing. Journal of the Human Environmental System; 12(1): 35-45. doi: 10.1618/jhes.12.35.

Misra M, Pacaud D, Petryk A, Collett-Solberg PF, Kappy M. 2008. Vitamin D deficiency in children and its management: Review of current knowledge and recommendations. Pediatrics; 122(2): 398-417. doi: 10.1542/peds.2007-1894. 
Mithal A, Wahl DA, Bonjour JP, Burckhardt P, Dawson-Hughes B, Eisman JA et al. 2009. Global vitamin D status and determinants of hypovitaminosis D. Osteoporosis International; 20(11):1807-1820. doi: 10.1007/s00198-009-0954-6.

Nair R, Maseeh A. 2012. Vitamin D: The "sunshine" vitamin. Practising Midwife, 15(9):14-16. doi: 10.4103/0976-500X.95506.

Nimitphong H, Holick MF. 2013. Vitamin D status and sun exposure in Southeast Asia. DermatoEndocrinology, 5(1):34-37. doi: 10.4161/derm.24054.

Pehlivan I, Hatun S, Aydogan M, Babaoglu K, Turker G, Gokalp AS. 2002. Maternal serum vitamin D levels in the third trimester of pregnancy. Turkish Journal of Medical Sciences; 32(3):237-241.

Putri NI, Lipoeto NI, Rita RS, Aji AS. 2019. Hubungan kadar vitamin D pada ibu hamil dengan berat bayi lahir di Kabupaten Tanah Datar dan Kabupaten Solok. Jurnal Ilmiah Universitas Batanghari Jambi; 19(1): 61-64. doi:10.33087/jiubj.v19i1.546

Ross AC, Taylor CL, Yaktine AL, Del Valle HB (eds.). 2011. Dietary Reference Intakes for Calcium and Vitamin D. Institute of Medicine of The National Academies (Vol. 32). Washington DC: The National Academies Press. doi: 10.17226/13050.

Sachdeva S. 2009. Fitzpatrick skin typing: applications in dermatology. Indian Journal of Dermatology, Venereology and Leprology, 75(1): 93-96. doi: 10.4103/0378-6323.45238.

Silvia E. 2019a. Analisis beberapa faktor yang berhubungan dengan kadar 25-

hidroksivitamin D serum pada perempuan remaja akhir. Thesis. Universitas

Andalas. Padang. Accessed from:http://scholar.unand.ac.id/43771/. 
Silvia E, Nasrul E, Ilmiawati C. 2019b. Hubungan kadar 25-hidroksivitamin D serum dengan latensi tidur pada perempuan remaja akhir. Jurnal Kesehatan Andalas; 8(1): 124-130.

Toko E, Sumba O, Daud I, Ogolla S, Majiwa M, Krisher J et al. 2016. Maternal vitamin D status and adverse birth outcomes in children from rural Western Kenya. Nutrients; 8(12): (794). doi:10.3390/nu8120794

Urrutia-Pereira M, Sole D. 2015. Deficiência de vitamina D na gravidez e o seu impacto sobre o feto, 0 recém-nascido e na infância. Revista Paulista de Pediatria; 33(1): 104-113. doi: 10.1016/j.rpped.2014.05.004.

Van der Mei IAF, Ponsonby AL, Engelsen O, Pasco JA, McGrath JJ, Eyles DW et al. 2007. The high prevalence of vitamin $D$ insufficiency across Australian populations is only partly explained by season and latitude. Environmental Health Perspectives; 115(8): 1132-1139. doi: 10.1289/ehp.9937.

Vidailhet M, Mallet E, Bocquet A, Bresson JL, Briend A, Chouraqui JP et al. 2012. Vitamin D: Still a topical matter in children and adolescents. A position paper by the Committee on Nutrition of the French Society of Paediatrics. Archives de Pédiatrie, 19(3): 316-328. doi: 10.1016/j.arcped.2011.12.015.

Wayako T, Belachew T, Vatanparast H, Whiting SJ. 2015. Vitamin D deficiency and its predictors in a country with thirteen months of sunshine: the case of school children in Central Ethiopia. Public Library Of Science; 10(3): 1-14. http://doi.org/10.1371/journal.pone.0120963.

Wen J, Kang C, Wang J, Cui X, Hong Q, Wang X et al. 2018. Association of maternal serum 25hydroxyvitamin D concentrations in second and third trimester with risk of macrosomia. Scientific Reports, 8(1): 6169. doi:10.1038/s41598-018-24534-5.

Yuan Y, Liu H, Ji C, Guo X, Hu L, Wen J et al. 2017. Association of maternal serum 25-hydroxyvitamin D concentrations in second trimester with delivery mode in a Chinese population. International Journal of Medical Sciences; 14(10): 1008. doi: 10.7150/ijms.20337. 


\section{Tables}

Page $11 / 14$ 
Table 1. Characteristics of pregnant Minangkabau women in late pregnancy $(\mathrm{n}=88)$

\begin{tabular}{|c|c|c|c|c|c|c|c|}
\hline Characteristic & $f$ & $\%$ & Mean & SD & Min & $\operatorname{Max}$ & Median \\
\hline Age (year) & & & 30.6 & 5:03 & 17 & 41 & 30.5 \\
\hline Gestational age (week) & & & 32.6 & 3.7 & 28 & 40 & 32 \\
\hline Number of pregnancy & & & 2.6 & 1.1 & 1 & 5 & 3 \\
\hline Upper arm circumference (cm) & & & 27.6 & 3.9 & 20 & 38 & 27 \\
\hline Skinfold thickness (cm) & & & 15.2 & 7.2 & 3 & 35 & 12 \\
\hline Serum 25(OH)D level (ng/ml) & & & 23.0 & 10.0 & 7.4 & 51.5 & 21.1 \\
\hline Defficiency $(<20$ ng/ml) & 40 & 45.5 & & & & & \\
\hline Insufficiency (20-31 ng/ml) & 32 & 36.4 & & & & & \\
\hline Sufficiency $(32-100$ ng/ml) & 16 & 18.2 & & & & & \\
\hline Vitamin D intake $(\mu \mathrm{g} / 1000 \mathrm{kcal} /$ day $)$ & & & 5.6 & 3.9 & 0.0 & 16.4 & 4.6 \\
\hline Sunlight exposed BSA (\%) & & & 15.2 & 6.8 & 4.9 & 28.4 & 15.8 \\
\hline $\begin{array}{l}\text { Duration of sunlight exposure } \\
\text { (minute/day) }\end{array}$ & & & 110.8 & 156.7 & 0:00 & 990 & 60 \\
\hline$<30$ & 26 & 29.5 & & & & & \\
\hline $30-60$ & 18 & 20.5 & & & & & \\
\hline$>60-120$ & 25 & 28.4 & & & & & \\
\hline$>120$ & 19 & 21.6 & & & & & \\
\hline
\end{tabular}

Skin pigmentation type (Fitzpatrick's scale)

$\begin{array}{lll}\text { III } & 1 & 1.1 \\ \text { IV } & 11 & 76 \\ \text { V } & 76 & 86.4\end{array}$

Sunscreen use

$\begin{array}{lll}\text { Regular } & 7 & 8 \\ \text { Irregular } & 11 & 12.5 \\ \text { Non-user } & 70 & 79.5\end{array}$

\section{Figures}




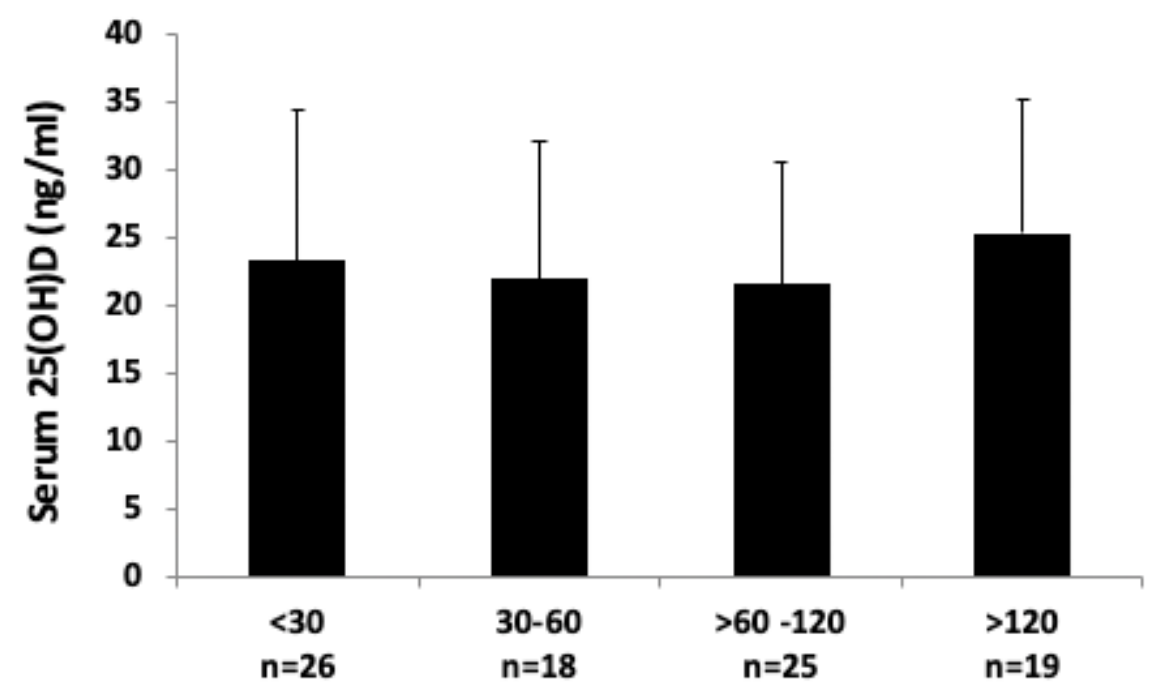

Duration of sunlight exposure (min/day)

Figure 1

Serum 25(OH)D level $(\mathrm{ng} / \mathrm{ml})$ of pregnant Minangkabau women in late pregnancy according to the duration of sunlight exposure (min/day). No statistically significant difference in serum 25(OH)D between groups ( $p=0.63$; One-Way ANOVA).

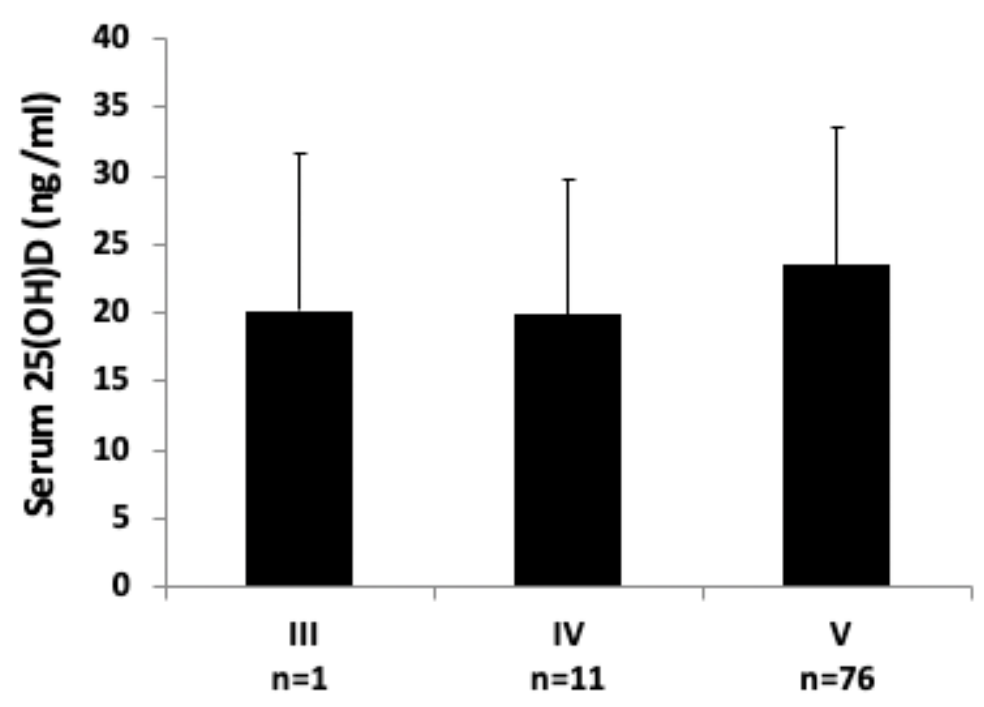

Skin pigmentation type

Figure 2

Serum 25(OH)D level $(\mathrm{ng} / \mathrm{ml})$ of pregnant Minangkabau women in late pregnancy according to their skin pigmentation type. No statistically significant difference in serum $25(\mathrm{OH}) \mathrm{D}$ between groups $(p=0.51$; OneWay ANOVA). 


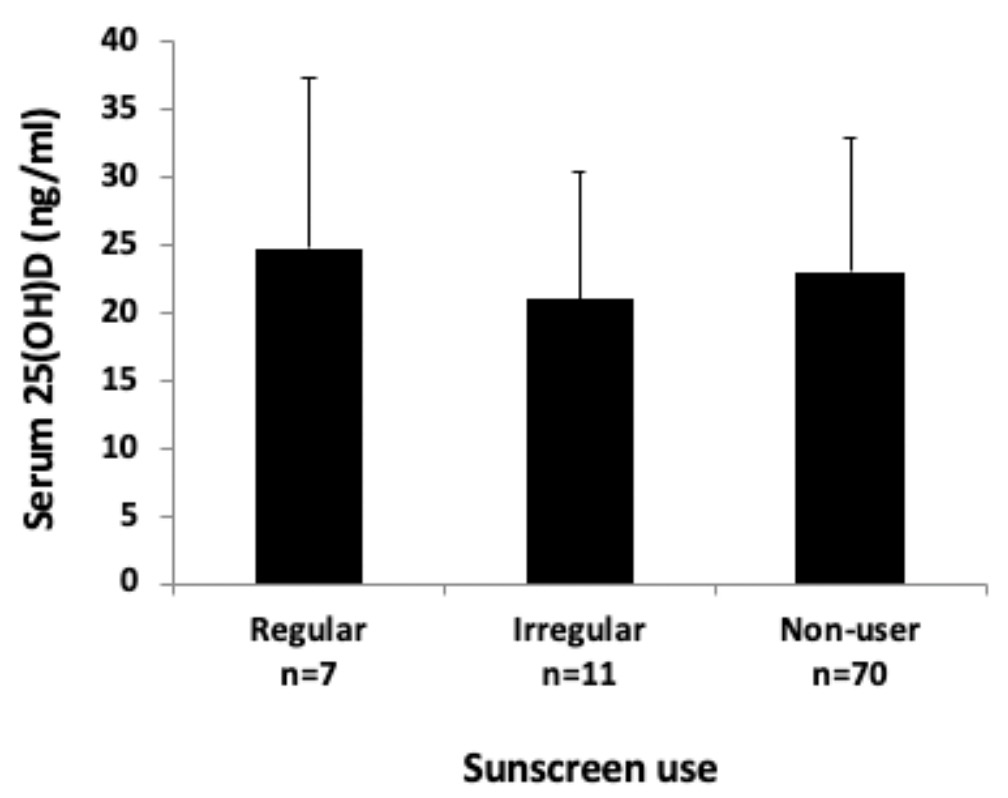

Figure 3

Serum 25(OH)D level $(\mathrm{ng} / \mathrm{ml})$ of pregnant Minangkabau women in late pregnancy according to their sunscreen use. No statistically significant difference in serum $25(\mathrm{OH}) \mathrm{D}$ between groups $(p=0.72$; One-Way ANOVA).

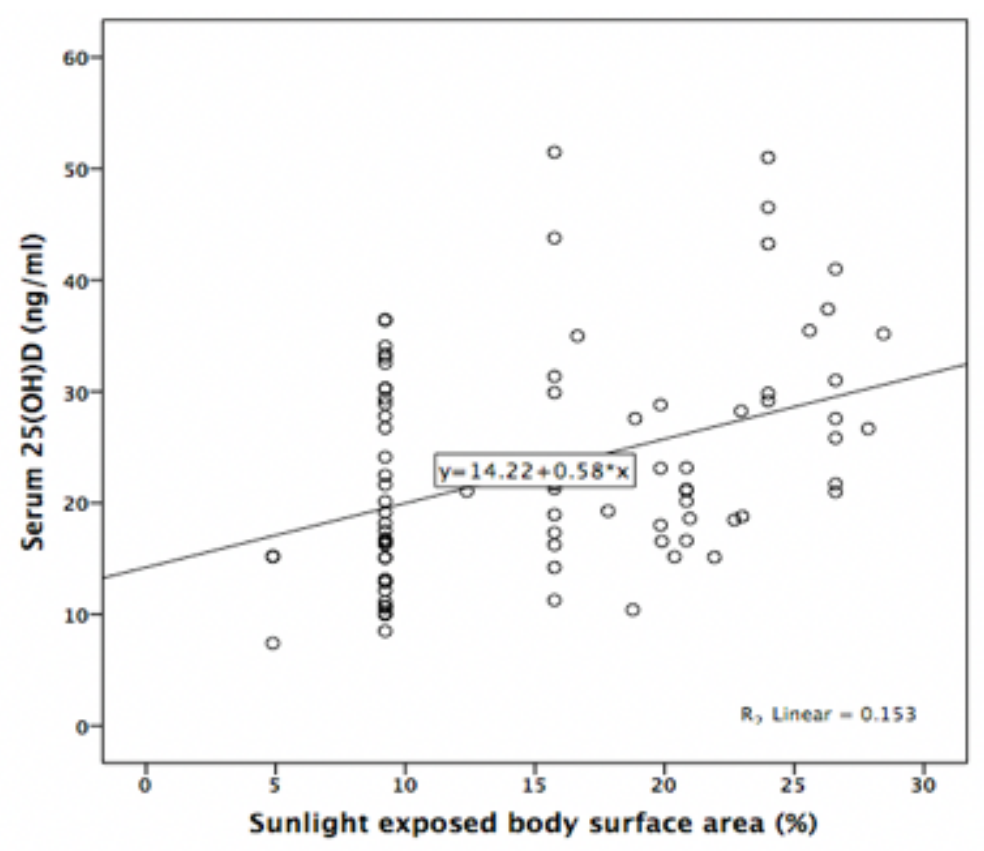

Figure 4

Correlation of serum 25(OH)D level $(\mathrm{ng} / \mathrm{ml})$ of pregnant Minangkabau women in late pregnancy with sunlight exposed body surface area $(\%)$ (Spearman's rho $=0.403 ; p=<0.001)$. 